\title{
How Do Companies Achieve Their Marketing Goals With Social Networks?
}

\author{
Marcello Sansone, Andrea Moretta Tartaglione, Roberto Bruni \\ University of Cassino and Southern Lazio, Cassino (FR), Italy
}

\begin{abstract}
This work examines the role of social network sites as a tool used by companies to achieve marketing goals. As known from the main business literature, the social network represents one of the most important instrument to improve the company fame by strengthening the affection of customers to the brand. For this reason, some companies use these tools to build relations and contacts with customers all over the world. The population of social networks users is made, for the most parts, of youngsters (people belonging to the 13-30 years old cluster). In the last years, with the social web networking, social communication lost the exclusive social meaning and social network sites become strategic instruments for the construction of powerful relations that connect people with people and people with firms. This work is aimed at clarifying the genesis and the evolution of the relations between companies and potential customers, focusing on the tools used by the firm to achieve their marketing goals through social network sites (SNSs). First of all, the work proposes the recognition of some studies about the origin of web social network and their links with marketing strategies. Secondly, it considers marketing goals achieved from any companies through social networking with a particular focus on advertising through web social networking.
\end{abstract}

Keywords: Social network sites (SNSs), marketing, youngers, brand value, relationship with customers

\section{The Origin of Marketing in Social Network Sites: From Social Marketing to Network Science}

Social marketing founds its origins in the 1970s, before these years it was possible to find only advertising awareness campaigns for public and social issue (Wiebe, 1951). According to McGovern (2007), social marketing aim is to understand how individuals percept themselves and firms and how the influence of others (of the group) can shape them in their behaviours (Pechman, 2002).

Between the 1970s and the 1980s different awareness campaigns on the theme of social advertising (e.g.,

Marcello Sansone, Professor in Business Management, Department of Economy and Law, University of Cassino and Southern Lazio.

Andrea Moretta Tartaglione, Assistant Professor in Business Management, Department of Economy and Law, University of Cassino and Southern Lazio.

Roberto Bruni, Research Fellow in Business Management, Department of Economy and Law, University of Cassino and Southern Lazio.

Correspondence concerning this article should be addressed to Andrea Moretta Tartaglione, Via Sant’Angelo Loc. Folcara snc, 03043, Cassino (FR), Italy. E-mail: a.moretta@unicas.it. 
campaigns on social responsibility, family, diseases) had been developed and the campaigns against smoke represented a specific example of this.

Social marketing campaigns became wider through the integrated marketing (Kotler \& Lee, 2007; Geary, 2007) and the relevance of the network role into the business world and society having represented the connection between marketing, internet, and social networking, in particular, there is a relevant literature on network science that represents the connection between social, business, and marketing studies. In this connection, we find studies on social marketing and social network marketing that find material instruments in Social network sites (SNSs). Some foundamental concepts have been studied in the past about network science: the different types of relation in networks (Lechner \& Dowling, 2003); survivor, performance, and development of entrepreneurial societies as focus of research (Gartner, 1985; Bygrave \& Hofer, 1991; Venkataraman, 1997; Shane \& Venkataraman, 2000). The network is a more important model of organizations development (Richardson, 1972; Powell, 1987, 1990). People are as resources in a network (Granovetter, 1974, 1985; Easton, 1992), the network is as particular form of governance and the loyalty in the network as relevant assets (Richardson 1972; Powell, 1987; Larson, 1992). The network takes different forms as time goes on (Larson, 1992).

Between 2005 and 2010, the internet use as promotion of the advertising campaigns began to take relevance because of the possibility, that this technological tool gives, to optimize relation and segmentation toward different customers with appropriate use of ad hoc messages and thanks to benefits that customers find in a correct behaviour toward society.

Some studies demonstrate that a high level of involvement and interactivity can give a better participation and a positive approach to websites (Kalyanaraman \& Sundar, 2003), this approach aims at a value co-creation and a powerful relations with customers. In particular, customers are particularly influenced by firms (Kreuter, 1999) but also by other customers that publish their considerations online (Awad, Dellarocas, \& Zhang, 2006; Weiss, 2008). Boyd and Ellison (2007) studying social network sites say that

Social network sites as web-based services that allow individuals to construct a public or semi-public profile within a bounded system, articulate a list of other users with whom they share a connection, and view and traverse their list of connections and those made by others within the system. The nature and nomenclature of these connections may vary from site to site. (p. 211)

New media can take advantage of social marketing benefits using some important tools: attention and conservation, for example, are two elements which carry out a kind of research about consumptions sounding out a very strong propension towards the use of new multimedia technologies in order to modify the individual attitude by underlining the importance of interactive tools (Ferney \& Marshall, 2006; Hu \& Sunder, 2010; Binks $\&$ Van Mierlo, 2010). New media technologies permit constant communication with customers and provide them opportunities to give and receive feedbacks. In particular, through integrated forms of communication (e-mails, messages), firms can try to modify long term practices of customers (verbal persuasion). Customers have an active role in the relation with SNSs because they can present data about their needs and developing, in this way, intervention and personalized objectives (control).

The technique of web marketing has to be integrated with the most recent social marketing, for companies, social marketing means to promote and to manage public relations in order to obtain reputation and loyalty. A 
correct activity of social media marketing implies the creation and management of a social profile through a website (facebook, twitter, google, linked in) which is correct, sincere and planned to permit a user friendly consultation.

Only few entrepreneurs (especially in Italy and between SMEs) use to manage social media marketing to improve the interaction with customers and, for example, to increase sales, loyalty, and brand value. Aversion to the use of social network sites is higher for small and medium enterprises which cannot coordinate themselves with the speed of the web (Freeman, 2010) and, frequently, have not economic and human resources to manage SNSs internally. At the same time, with the increase of the relevance of these instruments and strategies, some SMEs have known the power of these tools and, for this reason, have chosen on the one hand a direct management of social networks (expensive activity that give results in medium-long period) and, on the other hand, the investment in online advertisings using SNSs, this last tool contributes principally to the strengthening of brand value.

\section{The Youngers Cluster and Social Network Sites (SNSs)}

The youngers cluster is composed by young people that represent a target for many firms and the first supporters of Social Network Sites (SNSs). In this work, according to the European Commission, we consider in this cluster people are from 13 to 30 years old (SNSs are frequented also by people of other age clusters until 70 years old). The range name "youngers", now also accepted by the scientific community, has acquired this classification also according to some programs created by the European Commission independently of the research projects that involve the Internet. Just to study the age range of those who use Facebook or SNSs in general, it has been carried out a study of sampling and data collection based on researches that, in turn, have used data from university centre (Ellison, Steinfield, \& Lampe, 2007). In order to attract several people from a variety of States and Universities, the study has been founded on a Facebook research. In particular, the survey has been started by an email invitation sent through a Facebook account, for first to students of a university placed in the Midwestern United States, which asked them to forward the e-mail to their colleagues. Participation was voluntary and those who completed the survey received an extra credit as compensation for their involvement. In addition, all participants were included in a project which provided the delivery of a $\$ 50$ gift card for purchases to be done in any Apple Computer store, the online data revealed the participation of 302 members found in a limited geographic area and in a short time and most of them belonged to an age range that goes from 18 to 24 years old. This is an element that allows to perfectly understand the power of SNSs on the youngers. As in the USA, also in Italy the age range of SNSs frequently users refers to a cluster from 13 to 30 years old and it represents people who use SNSs especially to joke, to find new friends, to exchange considerations on products and services.

\section{Marketing and Social Network Sites (SNSs)}

SNSs allow the development of a value creation process within the customers' mind and it helps to enhance the perception of the brand value by strengthening the relationships between companies and customers. SNSs are used as tools to monitor, to report and to have a direct contact with customer and an amplification of business communication. 
The monitoring concept is complex but relevant in marketing and, in SNSs, it involves the control of posts, discussions, exchanges of information, and commentaries, but also the mood of customers in different stages of the business approaches (company and product offerings exploration, product-service purchase, aftersales). The relationship between firm and customer can be direct (business-to-customer) or indirect-in this case, the firm can monitor chats, comments from expert customers and firm, fans who express negative (or positive) opinions on the product-service performance.

The amplification concept of brands value, products, and firm services involves a planning of the marketing activities which is able to multiply the number of customers who speak about topics connected with the company, to increase the positive feedback about brands and products, to encourage the word—of mouth advertising among customers who have lost faith in traditional advertisings.

Hoang and Antoncic (2003) led for 15 years a research on the effects that the network (in general) has on firm activities. In a similar study, Kock and Coviello (2010) sustained that it could improve the activities of small and medium-sized enterprises and, in particular, they paid attention to the Information and Communication Technology (ICT) companies and their way of using the network to reach globalization. An efficient use of the network allows companies to overcome some obstacles such as their relatively small size, their lack of internal resources, their distance from international markets. Some searches have shown that SMEs can simplify the process of product sale in international markets through the efficient use of networks (Chetty \& Wilson, 2003; Coviello \& Munro, 1997).

The use of SNSs is therefore fundamental for the business activities of companies because they offer alternative strategies to improve the relation between firm and customer and to minimize, through web technology, the weaknesses that could come out starting a physical relational network. Through the SNSs, companies start various activities to enhance brand value, to acquire information, to develop the relationship with customers.

With a marketing approach, there are different schemes through which it is possible to analyse information and to empower customers relationship. Between the 1980s and the 1990s, the scheme of relational marketing analysed different tools to improve the customer relation with firms (call centre, information phone numbers, customer care supports, etc.), the main aim of these instruments was the empowerment of the relation with customers through the direct contact with them even if, often, the input of the report took place in an unidirectional manner (company-customer) and, sometimes, it was resolved with a response from the company though it came from the consumer. Through SNSs, companies move towards a value co-creation based on a continuous exchange of views and information on products/produced services.

The evolution of marketing studies brings the researcher to investigate the role of the brand and its position within the marketing strategy. In particular, thinking the brand as a relational network, some powerful investments, as social network sites, are right tools to strengthen the relation between customers and firms.

A first tool used for the collection of information is the social media monitoring which differs from traditional searches because it comes out of the classic rule of rigidly fixed questions and it allows to discover free comments and, sometimes, additional elements and comments on competitors' products. In social media monitoring, unlike the interviews, considerations are spontaneous and not constrained by the necessary response to a questionnaire or an interviewer; with the online publication of the answers, opportunities of involving and 
influencing other customers have proliferated and contributed to the generation of opinions and considerations. Most used tools are Social Mention, Addictomatic, IceRocket, and specific software such as: NetMiner, NodeXL, Gephi (Dardi, 2011).

With the development of these new technics in marketing management, the role of new managerial figures becomes relevant in the company:

- The social media manager who plans the development of activities on SNSs and defines team roles and responsibilities in goals;

- The community manager who manages company profiles on various social media monitoring conversations;

- The social media analyst who controls the online data, sentiments, and the relations with customers (Cosenza, 2010).

The conversation monitoring is very important because it allows to understand opinions, needs, languages, and customers' wishes. The following step is to establish a sincere dialogue with users, avoiding advertising tone because, otherwise, the company could be excluded from conversations in the medium and long period. In order to create and consolidate a relationship with a wide audience, especially the youngsters, companies must offer interesting, useful, and nice content.

\section{Strengths and Weaknesses of Advertising in SNSs}

Advertising is a relevant argument for SNSs and, sometimes, in SNSs, it has a viral form. Starting from Porter and Golan (2006) considerations, we can look at the viral advertising as a kind of provocative communication which influences and persuades users through the use of the Internet. Some studies indicate that emotion is a relevant component of the viral advertisings: Phelps, Lewis, Mobilio, Perry, and Raman (2004), for example, explaining how the sender of viral messages tends to produce emotions that lead customers to positively experience; Some authors argue that the emotional component plays a critical role in influencing customer behavior but, to do this, it is necessary that messages contain a sort of surprise; Still, Eckler and Bolls (2011) have studied how the emotional tone of viral video influenced users, in particular, young people involved in SNSs. SNSs have drastically changed the way in which customers respond to advertisements and not everybody, however, appreciate them on social networks. According to an AdReaction's study (2010), only the 22\% of customers had a positive attitude towards the viral advertisings, while the $8 \%$ of them left a SNS because they perceived an excess of the advertising ${ }^{1}$ activity. Anyway, there are also some other reasons that bring companies toward the disuse of social networks:

- the growing number of platforms that make it difficult to locate where conversations take place between users;

- the difficulty in measuring the return on investment;

- the difficulty of social media monitoring.

\footnotetext{
1 The decrease in the use of Myspace, for example, is principally due to the presence of unwanted and unsolicited advertising messages (Vara, 2006). Even Facebook has not been immune to the criticism about the use of advertising.
} 
The main obstacle to social networks advertising is the intrusiveness level perceived by users: an advertisement can be defined intrusive when it distracts or irritates the customers (Lee, 2002) (measuring the intrusiveness of advertisements: scale development and validation ).

Customers perceive an implicit social contract with advertisers in the case of traditional medias (television, radio, print) as they have free or reduce-price programs dedicated to advertising activities (Gordon \& De Lima-Turner, 1997). Vice versa Internet customers do not perceive the advertising as a contract, but as an intrusive and annoying deviation (Mathews, 2000; Gaffney, 2001). Nowadays, there are some studies suggesting that the most loyal users of the Internet perceive online advertisements as a negative factor as it imply the constant needs of protecting their privacies (Castaneda \& Montoro, 2007). The use of information collection, in fact, cannot be controlled and, frequently, users do not know that web sites are collecting their private data (Milne, 2000).

The online advertising is very important for business companies and users spend more and more time on SNSs: from an average of three hours per week in December 2008 we had got to an average of 5.5 hours per week during December 2010 (Nielsenwire, 2010). Researchers have argued that, at the same time, we have to understand why people use SNSs but also how they respond to the advertising activities (Rodgers \& Thorson, 2009). Some authors (Stafford, 2008; Stafford \& Schkade, 2004) have suggested that the main reasons which bring users to netsurf includes structural factors, content factors (information, entertainment), and socialization factors (for example, connecting with others). According to the theory of the uses and gratifications (Katz \& Foulkes, 1962), customers are actively seeking ways to satisfy needs both hedonistic and utilitarian, for example, they can watch television to be entertained by a movie or to be informed by a documentary or news program. Therefore, this theory shows that the value of an advertisement derives from its capacity to satisfy the needs of entertainment, evasion, fun, and emotional release of customers (McQuail, 1983).

Customers can use SNSs to escape from boredom but, often, these sites represent a part of their daily routine. Lull (1980) proposed a classification of utilitarian and hedonic motivations in media use, distinguishing structural dimension (the use of a media to have information or entertainment), and relational dimension (use a media to facilitate relations or interpersonal communications). Although the theory had been conceived to explain the use of television and other old forms of media, in the late 1990s it had also been applied to Internet world (Eighmey, 1997; Eighmey \& McCord, 1998; Stafford \& Schkade, 2004), viral advertising (Rodgers \& Thorson, 2000), mobile advertising (Peters, Amato, \& Hollenbeck, 2007), and SNSs studies (Joinson, 2008).

But what is the content an advertisement should have? According to some authors, the advertisment become relevant just for its informative content, i.e., a content that informs users about alternative products, social responsibility or environmental safeguard (Rotzoll, Haefner, \& Sondage, 1990). According to others, the advertisment has to show accurate representations of the products in order to guide the customer perception (Andrews, 1989), the content of an advertisment, according to some scholars (Darley, 1995) are perceived differently by men and women, as well as their motivations to use the Internet are different (Weiser, 2000; Wolin \& Korgaonkar, 2003 ), from this point of view, the information is also relevant for SNSs contents that improve the possibility to have a good visibility through different people genders. Men are more inclined to use the Internet for entertainment, while women use it to communicate or interact with others, also the idea each group has about privacy is different: women are in fact more predisposed to protect their privacies. At the same way, 
while adults care about the privacy invasion threatened by markets and information researchs, on the contrary teenagers and young adults freely disclose personal and private information on SNSs (Barnes, 2006). This reality creates, at the same time, an opportunity for firms and a risk for people, youngsters who become adults will have problems to shift their generality through a more reserved profile and, maybe, they could become the target of different firms that know these people since their young age. Barnes (2006) called this situation the privacy paradox: the author argues that it occurs when users, especially teenagers, are not aware of the Internet nature. However, Acquisti and Gross (2006) explained this phenomenon as a disconnection between the users' desire to protect their privacy and their effective behaviour, in the beginning, the SNSs have simply represented a means to send messages and view friends' photos, but later, many features had been added, including special interest groups (45 million in 2009), web links, news, and blogs.

\section{Managerial Implications and Practices}

SNSs do not have the same conformation all over the world although marketing goals are often the same in all countries: brand visibility, value and customer relation improvement, fidelization and loyalty to firm and to product/services. However in some countries, we find different approaches that involve different types of SNSs power.

There are a lot of case studies containing different experiences in different countries around the world to discuss.

In China, for example, because of the government censure, relevant SNSs cannot enter in the country and for this reason we just find the development of local social networks as RenRen, Weibo, Qzone and others, although this online social networks are unknown all over the world, they have millions of users in China.

The success of this social network is guaranteed and it represents an opportunity for firms that need advertisings in Chinese market. Demographic data, in fact, underline that the number of Chinese web users has increased: from 265 million in 2010 to 500 million in 2011. Some of these social networks, such as RenRen, Sina, and Weibon are also quoted on the stock exchange. Here is a brief list of firms present on these social networks: Lancome that guides the customers on the choice of beauty product; Louis Vuitton aims at high quality video, images, and events to attract customers. This demonstrates that Chinese social network have the same function of western ones: young Chinese users speak with their contemporaries through blogs and thanks to the advertisements inserted on them, they become loyal to a certain brand or product.

There are other successful cases of traditional companies:

FORD: when Ford entered for the second time the American market with Fiesta Subcompact Car model, it began a wide marketing campaign called Fiesta Movement. The video of Fiesta campaign have generated 6.5 milion of visualization on You Tube, and Ford has received 50,000 requests of information about the product, in particular from no-Ford-driver.

PepsiCO: PepsiCO used SNSs to find information about customers and it created a new brand for a new drink through a new campaign of promotion named DEWmocracy. In Italy, we can find many cases of SNSs use in marketing strategies by Ikea, Media World, Euronics, La Feltrinelli. In particular OssCom, Cattolica University's research centre of communication and media, and Digital PR, consulting agency of communication, have studied firms communication on social media in Italy, by monitoring the communication activities of 20 
chain stores active at national level in sport, clothes, customer electronics, publishing, and multimedia sector, they have drawn up a classification based on degree of exposition in social media, using of digital spaces and kinds of interaction with customers.

In particular, the positioning of the firms has been influenced by the frequency of profile revisions, but also by the amount of Facebook comments and links or Twitter retweet. The research has underlined that the highest step on the podium belongs to Ikea that implements communications strategies through an intensive multiplatform involving Facebook, Twitter, YouTube. Media World, Euronics and La feltrinelli implement similar strategies but they do not reach the same result of the Swedish brand. Ikea, in fact, gains success with its customers especially through comment on the projects and suggestion on products and combinations.

The most active sector on social media is that one referred to furniture and bricolage, publishing and multimedia, customer and electronic field. These sectors, in fact, use to work on constricted geographical zones so that SNSs become useful in order to calibrate offers, customize promotions, etc.. On the contrary, companies belonging to the clothing field, for example, as it is referred to a more global business, must take care of the relationship with a large amount of customers (which are different in each part of the world) and must also pay attention to the improvement of the brand reputation.

In short, nowadays, companies which use social media for their business cannot focus their attention, as in the past, just on the product that must be sponsored, but they must demonstrate a capability in shifting their focus especially on the relation with customers and brand reputation.

\section{References}

Achrol, R. S., \& Kotler, P. (2006). The service-dominant logic for marketing: A critique. In R. S. Lusch, \& S. L. Vargo (Eds.), The Service-Dominant Logic for Marketing: Dialog, Debate and Directions (pp. 320-333). Armonk, N.Y.: ME Sharpe.

Acquisti, A., \& Gross, R. (2005). Information revelation and privacy in online SN. Proceedings of WPES’05 (pp. 71-80). Alexandria, V.A.: ACM.

AdReaction (2010). Brands + Customer + Social media: What marketers shoud know about who's getting social and why. Retrieved from http://www.dynamiclogic.com

Anderson, J. C., Håkansson, H., \& Johanson, J. (1994). Dyadic business relationships within a business network context. Journal of Marketing, 58(October), 1-15.

Andrews, J. C. (1989). The dimensionality of beliefs toward advertising in general. Journal of Advertising, 18(1), 26-35.

Awad, N., Dellarocas, C., \& Zhang, X. (2006). The digital divide of word of mouth. Proceedings of the First Midwest United States Association for Information Systems. Grand Rapids, MI.

Barnes, S. B. (2006). A privacy paradox: Social networking in the United States', First Monday, 11(9). Retrieved July 21, 2008, from http://firstmonday.org/issues/issue11_9/barnes/index. html

Binks, M., \& Van Mierlo, T. (2010). Utilization patterns and user characteristics of an ad libitum internet weight loss program. Journal of Medical Internet Research, 12(1), 9-14.

Boyd, D. M., \& Ellison, N. B. (2007). Social network sites: Definition, history,and scholarship. Journal of Computer-Mediated Communication, 13(1), 210-230.

Bucy, E. P. (2003). The interactivity paradox: Closer to the news but confused. In E. P. Bucy, \& J. E. Newhagen (Eds.), Media Access: Social and Psychological Dimensions of New Technology Use (pp. 47-72). Mahwah, N.J.: Erlbaum.

Bygrave, D. W., \& Hofer, W. C. (1991). Theorizing about entrepreneurship. Entrepreneurship Theory \& Practice,16(2), 13-22.

Castaneda, J. A., \& Montoro, F. J. (2007). The effect of internet general privacy concern on customer behavior. Electronic Commerce Research, 7(2), 117-141.

Chetty, S. K., \& Wilson, H. M. (2003). Collaborating with competitors to acquire resources. International BusinessReview, 1(12), 61-81.

Cosenza, V. (2010). Social media ROI. Milano: Apogeo. 
Coviello, N. E., \& Munro, H. J. (1997). Growing the entrepreneurial firms: Networking for internal market development. European Journal of Marketing, 29(7), 49-61.

Dardi, F. (2011). Editore nei social media: incontrare i lettori nei social media. Milano: Apogeo.

Darley, S. (1995). Gender differences in information processing strategies: An empirical test of the selectivity model in advertising response. Journal of Advertising, 24(1), 41-56.

Dobele, A., Lindgreen, A., Beverland, M., Vanhamme, J., \& Van Wijk, R.(2007). Why pass on viral messages? Because they connect emotionally. Business Horizons, 50(4), 291-304.

Drucker, P. (1954). The practice of management. New York: Harper e Row.

Easton, G. (1992). Industrial networks: A review. In G. Easton (Ed.), Industrial networks: A new view of reality. London, Routledge.

Eckler, P., \& Bolls, P. (2011). Spreading the virus: Emotional tone of viral advertising and its effects on forwarding intentions and attitude. Journal of Interactive Advertising, 11(2), 1-11.

Eighmey, J. (1997). Profiling user responses to commercial web site. Journal of Advertising Research, 37(3), 59-66.

Eighmey, J., \& McCord, L. (1998). Adding value in the information age: Uses and gratifications of sites in the world wide web. Journal of the Business Research, 41(3),187-194.

Eisenhardt, K. M. (1989). Building theories from case study research. The Academy of Management Review, 14(4), 532-550.

Ellison, N. B., Steinfield, C., \& Lampe, C. (2007). The benefits of facebook friends': Social capital and college students' use of online SNS. Journal of Computer-Mediated Communication, 12(4), 1143-1168.

Felton, A. P. (1959). Making the marketing concept work. Harvard Business Review, 37, 55-65.

Ferney, S. L., \& Marshall, A. L. (2006). Website physical activity interventions: Preferences and potential users. Health Education Research, 21(4), 560-566.

Freeman, S. (2010). A model of rapid knowledge development: The smaller born-global-firms. International Business Review, 19(1), 70-84.

Gaffney, J. (2001). The battle over internet ads. Business 2.0, 25, 19-21.

Gartner, W. B. (1985). A conceptual framework for describing the phenomenon of new venture creation. Academy of Management Review, 10, 696-706.

Gilmore, A., \& Carson, D. (1999). Entrepreneurial marketing by networking. New England Journal of Entrepreneurship, 2(2), 31-38.

Gordon, E., \& De Lima-Turner, K. (1997). Customer attitudes towards internet advertising: A social contract prospective. International Marketing Review, 14(5), 362-375.

Granovetter, M. S. (1973). The strength of weak ties. American Journal of Sociology, 78, 1360-1380.

Granovetter, M. S. (1974). Getting a job: A study of contacts and careers. Boston M.A.: Harvard University Press.

Granovetter, M. S. (1985). Economic action and social structure: The problem of embeddedness. American Journal of Sociology, 91, 481-510.

Grönroos, C. (2006). What can a service logic offer marketing theory? In R. F. Lusch, \& S. L. Vargo (Eds.), The Service-Dominant logic of marketing: Dialog, debate, and directions (pp. 354-364). Armonk, N.Y.: ME Sharpe.

Gummesson, E. (2006). Many-to many marketing as grand theory. In S. L. Vargo, \& R. F. Lusch (Eds), The Service-Dominant Logic for marketing: Dialog, debate and directions (pp. 339-353). Armonk, N.Y.: ME Sharpe.

Hoang, H., \& Antoncic, B. (2003). Network-based research in entrepreneurship: A critical review. Journal of Business Venturing, 18(2), 165-187.

Hu, Y., \& Sunder, S. (2010). Effects of online sources on credibility and health behavioral intentions. Communications Research, 37(1), 105-132.

Johanson, J., \& Vahlne, J. E. (2003). Business relationships learning and commitment in the internationalization process. Journal of International Entrepreneurship, 1(1), 83-101.

Johnston, R., \& Jones, P. (2003). Service productivity: Towards understanding the relationship between operational and customer productivity. International Journal of Productivity and Performance Management, 53(3), 201-213.

Joinson, A. N. (2008). Looking at, looking up or keeping up with people: Motives and use of facebook. Proceedings of the 26th Annual SIGCHI Conference Human Factors in Computing Systems, Gauthersburg.

Kalyanaraman, S., \& Sundar, S. S. (2003). The psychological appeal of personalized online content: An experimental investigation of customized web portal. Paper presented at the meeting of the International Communication Association, san Diego. 
Katz, E., \& Foukles, D. (1962). On the use of the mass media as escape: Clarification of a concept. The Public Opinion Quarterly 26(3), 377-388.

Kock, S., \& Coviello, N. (2010). Entrepreneurship research on network processes: A review and ways forward. Entrepreneurship Theory and Practice, 34, 31-57.

Koplan, A., \& Haenlein, M. (2010). Users of the world, unite! the challenges and opportunities of social media. Business of Horizons, 53(1), 59-68.

Kotler, P., \& Lee, N. (2007). Social marketing: Influencing behaviors for good. Thousand Oak, C.A.: Sage Publications, Inc..

Kreuter, M. W. (1999). Understanding how people process health information: A comparison of tailored and untailored weight loss materials. Health Psychology, 18(5), 1-8.

Larson, A. (1992). Network dyads in entrepreneurial settings: A study of the governance of exchange relationships. Administrative Science Quarterly, 37(1), 76-104.

Lechner, C., \& Dowling, M. (2003). Firm networks: External relationships as sources for the growth and competitiveness of entrepreneurial firms. Entrepreneurship and Regional Development, 15, 1-26.

Lee, E. (2002). Measuring the intrusiveness of advertisements: Scale development and validation. Journal of Advertising, 31(2), 37-47.

Levitt, T. (1960). Marketing myopia. Harvard Business Review, 38, 45-56.

Lull, J. (1980). The social uses of television. Human Communication Research, 6(3), 197-209.

Malafarina, K., \& Loken, B. (1983). Progress and limitations of social marketing: A review of empirical literature on the consumption of social ideas. Advances in Customer Research, 20(1), 397-404.

Mathews, A. W. (2000). Advertisers find many web sites too tasteless. Wall Street Journal October, 12(2000), B1.

McGovern, E. (2007). Transport behavior: A role for social marketing. Journal of Nonprofit and Public SectorMarketing, 17(1/2), 121-134.

McQuail, D. (1983). Mass communication theory. London: Longman.

Michel, S., Brown, S. W., \& Gallan, A. S. (2008). An expanded and strategic view of discontinuous innovations: Deploying a service-dominant logic. Journal of Academy of Marketing Science, 36(1), 54-66.

Milne, G. R. (2000). Privacy and ethical issues in database interactive marketing and public policy: A research framework and overview of the special issue. Journal of Public Policy \& Marketing, 19(1), 1-6.

Morrisey, B. (2009). Brands seek fans on advertising. Retrieved October 12, 2009, from http://www.adweek.com/news/advertising-branding/brands-seek-fans-facebook-104999

Nielsenwire. (2010). Led by Facebook, Twitter, global time spent on social media sites up 82 percent year over year. Retrieved from http://blog.nielsen.com/nielsenwire/global/led-by-facebook-twitter-global-time-spent-on-social-media-sites-up-82-year-overyear/

O’Donnell, A. (2001). The network construct in entrepreneurship research: A review and critique. Management Decision, 39(9), 749-760.

Pechman, C. (2002). Overview of the special issue on social marketing initiatives. Journal of the Public Policy and marketing, 21(1), $1-2$.

Peters, C., Amato, C. H., \& Hollenbeck, C. R. (2007). An exploratory investigation of customers perceptions of wireless advertising. Journal of Advertising, 36(4), 129-145.

Phelps, J. E., Lewis, R., Mobilio, L., Perry, D., \& Raman, N. (2004). Viral marketing or electronic word-of-mouth advertising: Examining consumer responses and motivations to pass along email. Journal of Advertising Research, 44, 333-348.

Porter, L., \& Golan, G. J. (2006). From subservient chickens to brawnymen: A comparison of viral advertising to television advertising. Journal of Interactive Advertising, 6(2), 26-33.

Powell, W. W. (1987). Hybrid organizational arrangements: New form of transitional development? California Management Review, 30(1), 67-87.

Powell, W. W. (1990). Neither market nor hierarchy: Network firms of organization. In B. M. Staw, \& L. L. Cummints (Eds.), Research in Organizational Behavior, 12, 295-336.

Richardson, G. B. (1972). The organization of industry. Economy Journal, 82, 883-896.

Rodgers, S., \& Thorson, E. (2000). The interactive advertising model: How users perceive and process online ads. Journal of Interactive Advertising, 1(1), 26-50.

Rodie, A. R., \& Klein, S. S. (2000). Customer partecipation in services production and delivery. In T. Swartz, \& D. Iacobucci (Eds), Handbook of Services Marketing Management (pp. 111-125). Thousand Oaks, C.A.: sage. 
Rotzoll, K. B., Haefner, J. E., \& Sondage, C. H. (1990). Advertising in contemporary society. Cincinnati, O.H.: South Western. Shane, S., \& Venkataraman, S. (2000). The promise of entrepreneurship as a field of research. Academy of Management Review, 25, 217-226.

Song, J. H., \& Zinkhau, G. M. (2008). Determinants of perceived web site interactivity. Journal of Marketing, 72, 99-113.

Stafford, T. F. (2000). Identifying the users and gratifications of web use. Proceedings of the 2000 Conference of the American Academy of Advertising. Beachwood, O.H.: American Academy of Advertising.

Stafford, T. F. (2008). Social and usage- process motivation for customer internet access. Journal of Organizational \& End User Computing, 20(3), 1-21.

Stafford, T. F., \& Schkade, L. L. (2004). Determing uses and gratification for the internet. Decision Science, 35(2), $259-288$.

Steuer, J. (1992). Defining virtual reality: Dimensions determining telepresence. Journal of Communication, 42(4), 73-93.

Vara, V. (2006). myspace, bye space: Some users renounce social sites as too big. Wall Street Journal October, $26(2006)$, B1.

Vargo, S. L., \& Lusch, R. F. (2004). Evolving the new dominant logic for marketing. Journal of Marketing, 68(1), 1-17.

Venkataraman, S. (1997). The distinctive domain of entrepreneurship research: An editor's prospective. In J. Katz, \& R. Brockhaus (Eds), Advances in entrepreneurship, firm emergence and growth. Greenwich C.T.: JAI Press.

Weiser, E. B. (2000). Gender differences in internet use patterns and internet application preferences: A two-sample comparison. Cyber Psychology \& Behavior, 3(2), 167-178.

Weiss, A. M. (2008). Listening to strangers: Whose responses are valuable, how valuable are they, and why? Journal of Marketing Research, 45(4), 425-436.

Wiebe, G. D. (1951). Merchandising commodities and citizeniship on television. Public Opinion Quarterly, 15(4), 679-691.

Wind, J., \& Rangaswamy, A. (2001). Customization: The next revolution in mass customization. Journal of Interactive Marketing, 15(1), 13-32.

Wolin, L. D., \& Korgaonkar, P. (2003). Web advertising: Gender differences in beliefs, attitudes and behavior. Internet Research 13(5), 375-385.

York, E. R. (2009). Red robin calls in a facebook favour from 1500 fans: Casual-dining chain uses reccommendation app to turn passive customers into brand ambassadors. Adweek, 28(2009), 20. 